\title{
PENGARUH NPL, CAR, ROA DAN BI RATE TERHADAP PENYALURAN KREDIT PADA BANK UMUM YANG TERDAFTAR DI BURSA EFEK INDONESIA PERIODE 2014 - 2016
}

\author{
Eling Ri Kurniati ${ }^{1}$; Febriana Eriska Putri ${ }^{2}$ \\ STIE Tamansiswa Banjarnegara Jl. Mayjend Panjaitan No. 29 Banjarnegara \\ Email: elingri78@gmail.com ${ }^{1}$; putryeriska@gmail.com ${ }^{2}$
}

\begin{abstract}
The problem on this research was the number of internal and external factors of the bank that affect lending to commercial banks.This research aimed to analyze the effect of partial Non Performing Loans (NPL), Capital Eduquecy Ratio (CAR), Return On Assets (ROA) and BI Rate on lending to commercial banks, and analyze the influence of Non Performing Loan (NPL) variables, Capital Eduquecy Ratio (CAR), Return On Assets (ROA) and BI Rate simultaneously to lending to commercial banks. This research was associative causal. The data used in this research was secondary data from the results of Bank Indonesia publications and the official IDX website at www.idx.co.id. The population on this research were all publicly traded public banks listed on the IDX. The sampling technique in this research used purposive sampling method. The total sample in this research were 25 banks. Data Analysis in this research using multiple linear regression analysis with SPSS software. The results showed that the partial Non Performing Loans (NPL), Capital Eduquecy Ratio (CAR), and BI Rate did not affect credit distribution while the Return on Assets (ROA) variable partially affected the lending. Simultaneously the Non Performing Loan variable (NPL), Capital Eduquecy Ratio (CAR), Return On Assets (ROA) and the BI Rate have an effect on lending.
\end{abstract}

Keywords: Banks, Credit, Non Performing Loans (NPL), Capital Adequacy Ratio (CAR), BI Rate. 


\section{PENDAHULUAN}

\section{Latar Belakang}

Perkembangan perekonomian di Indonesia saat ini sangat tergantung pada lembaga keuangan. Salah satu lembaga keuangan yang mampu meningkatkan perkembangan ekonomi di Indonesia adalah perbankan. Menurut UU No. 10 Tahun 1998 tentang perbankan, bank adalah badan usaha yang menghimpun dana dari masyarakat dalam bentuk simpanan dan menyalurkannya kepada masyarakat dalam bentuk kredit dan bentuk-bentuk lainnya dalam rangka meningkatkan taraf hidup rakyat banyak. Dengan demikian bank merupakan bagian dari lembaga keuangan yang memiliki fungsi intermediasi yang menjembatani kepentingan pihak yang kelebihan dana (penyimpan dana atau kreditor) dan pihak yang membutuhkan dana (peminjam dana atau debitor).

Pemberian kredit merupakan aktivitas bank yang paling utama dalam menghasilkan keuntungan, tetapi risiko terbesar dalam bank juga bersumber dari pemberian kredit. Oleh karena itu pemberian kredit harus diawasi dengan manajemen resiko yang ketat. Agar dapat meningkatkan penyaluran kredit, pihak bank harus mengetahui faktor - faktor yang mempengaruhi penyaluran kredit, diantaranya terdapat dua faktor yaitu faktor internal dan faktor eksternal. Penelitian ini mengambil beberapa faktor internal dan faktor eksternal yang mempengaruhi penyaluran kredit, faktor internal yang digunakan adalah NPL, CAR dan ROA, sedangkan faktor eksternal yang digunakan adalah $\mathrm{BI}$ rate.

Vol. 11, No. 1, Juli 2020, Halaman 71-84
Berdasarkan Statistik Perbankan Indonesia BI tahun 2016 rasio NPL dari tahun 2014-2016 mengalami peningkatan tiap tahunnya padahal total kredit dari tahun 2014 - 2016 mengalami penurunan presentase kenaikan total kredit, hal ini menunjukan tingkat resiko kredit bermasalah semakin meningkat tiap tahunnya. Rasio CAR mengalami kenaikan dari tahun 2014-2016, hal ini menandakan bahwa naiknya modal bank maka total kredit juga ikut naik, sedangkan untuk rasio ROA pada tahun 2014 mengalami kenaikan $2,85 \%$ dari $2,43 \%$ pada tahun 2013 tetapi pada tahun 2015 - 2016 mengalami penurunan presentase berturutturut 2,32\% pada tahun 2015 dan 2,23\% pada tahun 2016. Pada tahun 2014 disini dapat dilihat meskipun presentase kenaikan total kredit menurun tetapi ROA meningkat hal ini dapat dipengaruhi oleh faktor lain yaitu suku bunga.

Berdasarkan Statistik Perbankan Indonesia BI tahun 2016 tampak fenomena GAP pada rasio NPL dimana rasio NPL tiap tahunnya mengalami kenaikan searah dengan penyaluran kredit yang mengalami kenaikan, hal tersebut tidak sesuai dengan Risk Absorption Theory dimana kenaikan risiko seharusnya mengurangi volume kredit yang disalurkan. Rasio CAR tiap tahunnya mengalami kenaikan berbanding terbalik dengan presentase kenaikan total kredit yang mengalami penurunan berturutturut hal tersebut tidak sesuai dengan Banking Capital Theory yang menjelaskan bahwa apabila modal bank besar maka modal tersebut digunakan untuk penyaluran kredit sehingga jumlah kredit besar. 
Sedangkan untuk rasio ROA pada tahun 2014 mengalami kenaikan sebesar 2,85\% tidak searah dengan pergerakan presentase kenaikan total kredit pada tahun tersebut yang mengalami penurunan, pada tahun 2015-2016 rasio ROA mengalami penurunan berturut -turut dari 2,32\% pada tahun 2015 dan 2,23\% pada tahun 2016 searah dengan pergerakan presentase total kredit yang mengalami penurunan juga.

\section{Rumusan Masalah}

1. Bagaimana pengaruh Non Performing Loan (NPL) terhadap penyaluran kredit pada Bank Umum?

2. Bagaimana pengaruh Capital Adequecy Ratio (CAR) terhadap penyaluran kredit pada Bank Umum?

3. Bagaimana pengaruh Return On Assets (ROA) terhadap penyaluran kredit pada Bank Umum?

4. Bagaimana pengaruh BI Rate terhadap penyaluran kredit pada Bank Umum?

5. Bagaimana pengaruh Non Performing Loan (NPL), Capital Adequecy Ratio (CAR), Return On Assets (ROA) dan BI Rate terhadap penyaluran kredit pada Bank Umum?

\section{METODE PENELITIAN}

\section{Lokasi Penelitian}

Penelitian ini dilakukan dengan mengambil data sekunder dari hasil publikasi Bank Indonesia, dan situs resmi BEI pada www.idx.co.id.

\section{Jenis Penelitian}

Penelitian ini tergolong penelitian kuantitatif.

\section{Variabel Penelitian}

a. Variabel Dependen Penyaluran Kredit (Y)

b. Variabel Independen

Non Performing Loan (X1)

Capital Adequacy Ratio (X2)

Return On Assets (X3)

$\mathrm{BI}$ rate $(\mathrm{X} 4)$

\section{Devinisi Konsep dan Operasional Variabel}

1. Non Performing Loan (NPL)

Non Performing Loan (NPL) merupakan rasio keuangan pokok yang dapat memberikan informasi penilaian atas kondisi permodalan, rentabilitas, risiko kredit, risiko pasar dan likuidasi. Berdasarkan SE BI Nomor. 6/23/DPNP Tahun 2004 perhitungan NPL dapat dihitung dengan rumus sebagi berikut:

$$
\text { NPL }=\frac{\text { Kredit Bermasalah }}{\text { Total kredit }} \times 100 \%
$$

\section{Capital Adequecy Ratio (CAR)}

Capital Adequacy Ratio menurut Dendawijaya (2008:122) adalah Rasio yang memperlihatkan seberapa jauh seluruh aktiva bank yang mengandung risiko (kredit, penyertaan, surat berharga, tagihan pada bank lain) ikut di biayai dari dana modal sendiri bank disamping memperoleh dana-dana dari sumber - sumber di luar bank, seperti dana dari masyarakat, pinjaman, dan lain-lain. Berdasarkan SE BI Nomor. 6/23/DPNP Tahun 2004 perhitungan NPL dapat dihitung dengan rumus sebagai berikut: 


$$
\text { CAR }=\frac{\text { Modal }}{\text { ATMR }} \times 100 \%
$$

3. Return On Assets (ROA)

Return on assets (ROA) merupakan salah satu rasio profitabilitas yang dapat mengukur kemampuan perusahaan dalam menghasilkan laba dari aktiva yang digunakan. Perhitungan ROA dapat dirumuskan sebagai berikut:

$$
\begin{aligned}
& \text { ROA = Laba setelah pajak } \\
& \text { Total aktiva }
\end{aligned}
$$

\section{BI Rate}

BI Rate adalah suku bunga instrumen sinyaling Bank Indonesia yang ditetapkan pada RDG (Rapat Dewan Gubernur) triwulanan untuk berlaku selama triwulan berjalan (satu triwulan), kecuali ditetapkan berbeda oleh RDG bulanan dalam triwulan yang sama

\section{POPULASI, SAMPEL DAN TEKNIK SAMPEL}

Populasi dalam penelitian ini adalah seluruh bank umum Go Public yang terdaftar di BEI. Sedangkan sampel yang digunakan dalam penelitian ini adalah bank umum yang terdaftar di Bursa Efek Indonesia tahun 2014-2016 berjumlah 32 bank. Teknik pengambilan sampel dalam penelitian ini menggunakan metode purposive sampling. Penelitian ini menggunakan teknik analisis regresi linier berganda.

\section{HASIL PENELITIAN}

1. Uji Asumsi Klasik

a. Hasil uji Normalitas

Uji normalitas ini bertujuan untuk menguji apakah dalam model regresi variabel terikat dan bebas memiliki distribusi normal. Metode regresi yang baik adalah memiliki distribusi data normal atau mendekati normal. Hasil scatter plot untuk uji normalitas adalah sebagai berikut:

Uji Normalitas Probability Plot

\section{Gambar 1}

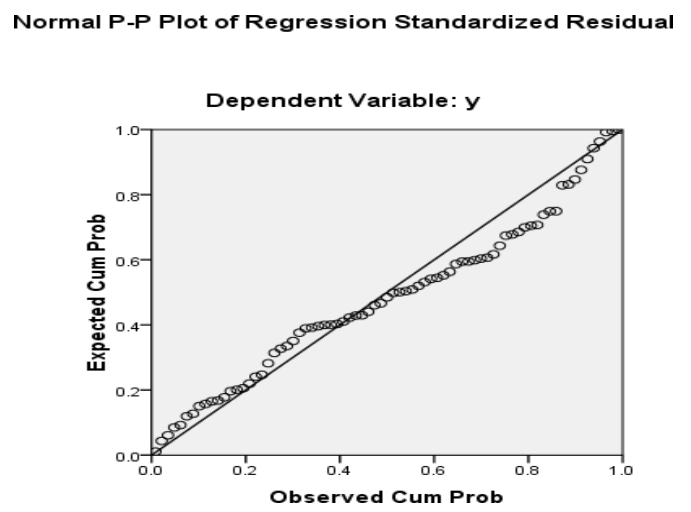

Berdasarkan gambar 1 di atas dapat kita lihat bahwa data terdistribusi secara normal yaitu persebaran data mengikuti garis diagonal yang ada. Sehingga dapat disimpulkan bahwa residual terdistribusi normal.

\section{b. Hasil Uji Multikolinearitas}

Uji Multikolinearitas ini bertujuan untuk menguji apakah dalam model regresi yang terbentuk terdapat korelasi diantara variable bebas atau tidak. Hasil uji multikolinearitas dalam penelitian ini dapat dilihat pada Tabel berikut: 
Tabel 1

Uji Multikolinearitas

\begin{tabular}{|r|c|c|}
\hline \multirow{2}{*}{ Model } & \multicolumn{2}{|c|}{ Collinearity Statistics } \\
\cline { 2 - 3 } & Tolerance & VIF \\
\hline 1 & & \\
(Constant) & & \\
X1 & .838 & 1.193 \\
X2 & .764 & 1.309 \\
X3 & .787 & 1.270 \\
X4 & .809 & 1.236 \\
\hline
\end{tabular}

a. Dependent Variable : $\mathrm{y}$

Berdasarkan Tabel 1 dapat diketahui nilai tolerance untuk seluruh variabel independen tolerance $>0,10$ dan nilai VIF $<10$. Hal ini dapat disimpulkan bahwa tidak terdapat multikolinearitas antar variable bebas dalam model regresi ini.

\section{c. Hasil Uji Heteroskedastisitas}

Hasil pengujian heterokedastisitas yang dilakukan terhadap penelitian ini dapat dilihat pada Tabel 2 berikut:

Tabel 2 Hasil Uji Park

\begin{tabular}{|l|c|c|c|c|c|}
\hline \multirow{2}{*}{ Model } & \multicolumn{2}{|c|}{$\begin{array}{c}\text { Unstandardized } \\
\text { Coefficients }\end{array}$} & $\begin{array}{l}\text { Standardized } \\
\text { Coefficients } \\
\text { Beta }\end{array}$ & $\mathrm{t}$ & Sig \\
\cline { 2 - 6 } & $\mathrm{B}$ & tdd. Eror & Beta & \\
\hline (constant) & 39.762 & 17.223 & & 2.309 & .024 \\
\hline Inx1 & 10.521 & 7.833 & 3.039 & 1.343 & .184 \\
\hline Inx2 & -10.023 & 0.847 & -1.684 & 1.018 & .12 \\
\hline Lnx3 & 13.093 & 10.062 & 2.039 & 1.301 & .197 \\
\hline Lnx4 & -19.072 & 15.724 & -2.674 & -1.213 & .229 \\
\hline
\end{tabular}

Berdasarkan hasil Uji Park di atas diketahui bahwa yaitu t hitung $\ln x 1(1,343)$, $\ln x 2(-1,018), \ln x 3(1,301), \ln x 4(-1,213)<\mathrm{t}$ table $(1,994)$ dan signifikan hitung $\ln x 1(0,184), \ln x 2(0,312), \ln x 3(0,197)$ dan $\ln x 4(0,229)$ tingkat signifikansi seluruh variabel indpenden berada di atas nilai
0,050. Maka hal ini membuktikan bahwa penelitian ini bebas dari masalah heterokedastisitas.

\section{d. Uji Autokorelasi}

Uji Autokorelasi bertujuan untuk menguji apakah dalam model regresi linear ada korelasi antara kesalahan pengganggu pada periode $\mathrm{t}$ dengan kesalahan pengganggu pada periode t-1 (sebelumnya). Hasil pengujian autokorelasi dalam penelitian ini dapat dilihat pada tabel 3 berikut:

Tabel 3

HasilUji autokorelasi

Model Summary ${ }^{\mathrm{b}}$

\begin{tabular}{|l|l|}
\hline Model & Durbin - Watson \\
\hline 1 & 2.295 \\
\hline
\end{tabular}

Sumber : Hasil Output SPSS

Hasil perhitungan uji Durbin Watson yang diperoleh adalah sebesar 2,295, lalu hasil ini akan dibandingkan dengan nilai dl dan du yang diperoleh dari tabel Durbin Watson. Jumlah sampel sebanyak 75 dengan 4 variabel independen diperoleh nilai dl sebesar 14866 dan du sebesar 1,7698. Berdasarkan nilai hitung di atas, dapat dinyatakan bahwa penelitian ini bebas dari masalah autokorelasi.

\section{Analisis Regresi Berganda}

Berdasarkan hasil uji asumsi klasik di atas dapat disimpulkan bahwa data yang digunakan dalam penelitian ini terdistribusi secara normal sehingga memenuhi persyaratan untuk melakukan analisis regresi berganda serta melakukan pengujian 
terhadap hipotesis. Pembuatan persamaan regresi berganda dapat dilakukan dengan menginterpretasikan angka-angka yang ada di dalam unstandardized coefficient Beta pada Tabel 4 berikut :

Tabel 4

Persamaan Regresi Berganda

\begin{tabular}{|c|c|c|c|c|c|c|}
\hline \multicolumn{7}{|c|}{ Coefficients } \\
\hline \multirow{2}{*}{\multicolumn{2}{|c|}{ Model }} & \multicolumn{2}{|c|}{$\begin{array}{l}\text { Unstandardized } \\
\text { Coefficients }\end{array}$} & \multirow{2}{*}{$\begin{array}{c}\begin{array}{c}\text { Standardized } \\
\text { Coefficients }\end{array} \\
\text { Beta }\end{array}$} & \multirow{2}{*}{$\mathrm{t}$} & \multirow{2}{*}{ Sig } \\
\hline & & B & Std. Eror & & & \\
\hline \multirow[t]{4}{*}{1} & (constant) & 208631.431 & 280151.300 & 165 & .745 & .459 \\
\hline & Lnx2 & -8421.370 & $\begin{array}{r}1494.5134 .383 \\
\end{array}$ & $\begin{array}{l}.105 \\
-.169\end{array}$ & 1640 & .105 \\
\hline & Lnx3 & 117426.234 & 16258.111 & .732 & 7.223 & .000 \\
\hline & $\operatorname{Ln} x_{4}$ & -29735.733 & 30655.261 & -.097 & -.970 & .335 \\
\hline
\end{tabular}

Berdasarkan tabel 4 di atas maka dapat disusun persamaan regresi berganda sebagai berikut:

Kredit $=208.631,431+25.063,181 X 1$

$-8.421,370 X 2+117.426,234 X 3-$ 29.735,733X4 + e

Berdasarkan persamaan regresi diatas maka dapat kita interprestasikan beberapa hal antara lain sebagai berikut:

a. Nilai konstanta persamaan diatas adalah sebesar 208.631,431 yang dapat diartikan bahwa kredit akan bernilai 208.631,431 satuan jika variabel seperti NPL, CAR, ROA dan BI Rate adalah tidak ada.

b. Variabel NPL memiliki nilai koefisien regresi positif yaitu sebesar 25.063,181. Nilai koefisien yang positif menunjukan bahwa NPL terhadap penyaluran kredit berpengaruh positif. Hal ini menggambarkan bahwa jika terjadi kenaikan nilai NPL sebanyak 1 persen maka akan menyebabkan kenaikan nilai penyaluran kredit sebesar 25.063,181 rupiah dengan asumsi variabel independen yang lain dianggap konstan.

c. Variabel CAR memiliki nilai koefisien regresi negatif yaitu sebesar -8.421,370. Nilai koefisien yang negatif menunjukan bahwa CAR terhadap penyaluran kredit berpengaruh negatif. Hal ini menggambarkan bahwa jika terjadi penurunan nilai CAR sebanyak 1 persen maka akan menurunkan nilai penyaluran kredit sebesar 8.421,370 rupiah dengan asumsi variabel independen yang lain dianggap konstan.

d. Variabel ROA memiliki nilai koefisien regresi positif yaitu sebesar 117.426,234. Nilai koefisien yang positif menunjukan bahwa ROA terhadap penyaluran kredit berpengaruh positif. Hal ini menggambarkan bahwa jika terjadi kenaikan nilai ROA sebanyak 1 persen maka akan menyebabkan kenaikan nilai penyaluran kredit sebesar 117.426,234 rupiah dengan asumsi variabel independen yang lain dianggap konstan.

e. Variabel BI Rate memiliki nilai koefisien regresi negatif yaitu sebesar -29.735,733. Nilai koefisien yang negatif menunjukan bahwa BI Rate terhadap penyaluran kredit berpengaruh negatif. Hal ini menggambarkan bahwa jika terjadi penurunan nilai BI Rate sebanyak 1 
persen maka akan menurunkan penyaluran kredit sebesar 29.735,733 rupiah dengan asumsi variabel independen yang lain dianggap konstan.

3. Uji Hipotesis

$$
\text { a. Uji F }
$$

Hasil uji $\mathrm{F}$ dalam penelitian ini disajikan dalam tabel 5 berikut:

Tabel 5

\section{Hasil Uji F}

ANOVA $^{b}$

\begin{tabular}{|l|l|l|l|l|l|}
\hline Model & $\begin{array}{l}\text { Sum of } \\
\text { Squares }\end{array}$ & df & $\begin{array}{l}\text { Mean } \\
\text { Square }\end{array}$ & F & Sig \\
\hline Regression & 8.066 E11 & 4 & $2.230 \mathrm{~F} 11$ & 13.450 & $000^{2}$ \\
\hline Residual & $1.164 \mathrm{E} 12$ & 70 & $1.664 \mathrm{E} 10$ & & \\
\hline Iotal & $2.060 \mathrm{E} 12$ & 74 & & & \\
\hline
\end{tabular}

a. Predictors: (Constant), $x 4, \times 3, x 2, \times 1$

b. Dependent Variable: $: y$

Berdasarkan Tabel 5 di atas dapat

kita lihat bahwa uji simultan ini menghasilkan nilai $f$ hitung sebesar $13.459>$ f table $(2,50)$ dan signifikan hitung $0,000<0,050$. Ini menunjukkan bahwa variabel independen yang antara lain Non Performing Loan (NPL), Capital Adequacy Ratio (CAR), Return On Asset (ROA) dan BI Rate secara bersama - sama mempengaruhi penyaluran kredit secara signifikan. Jadi hipotesis kelima yang menyatakan NPL, CAR, ROA dan BI Rate berpengaruh secara simultan terhadap penyaluran kredit. Ha diterima dan Ho ditolak jadi Hipotesis ke-5 diterima.

b. Uji Koefisien Determinasi $\left(\mathrm{R}^{2)}\right.$

Penelitian ini menggunakan adjusted

$\mathrm{R}^{2}$ karena nilai ini tidak akan

Vol. 11, No. 1, Juli 2020, Halaman 71-84 naik atau turun meskipun terdapat penambahan variabel independen ke dalam model. Nilai adjusted $\mathrm{R}^{2}$ tersebut akan tampak pada Tabel 6 berikut:

Tabel 6

Hasil Uji Koefisien Determinasi

Model Summary ${ }^{\mathrm{b}}$

\begin{tabular}{|r|r|r|r|r|r|}
\hline Model & $R$ & $R$ Square & $\begin{array}{l}\text { Adjusted } \\
\text { R Square }\end{array}$ & $\begin{array}{r}\text { Std. Error of } \\
\text { the Estimate }\end{array}$ & $\begin{array}{c}\text { Durbin - } \\
\text { Watson }\end{array}$ \\
\hline 1 & $.659^{2}$ & .435 & .402 & 128977.075 & 2.29 .5 \\
\hline
\end{tabular}

a. Predictors : (Constant), $\mathrm{x} 4, \mathrm{x} 3, \mathrm{x} 2, \mathrm{x} 1$

b. Dependent Variable : y

Berdasarkan tabel diatas, diperoleh nilai R Square sebesar 0,435. Hal tersebut menunjukkan bahwa kemampuan variabel independen (NPL, CAR, ROA, BI Rate) dalam menjelaskan besarnya pengaruh terhadap variabel dependen (penyaluran kredit)

adalah sebesar $43,5 \%$, sedangkan sisanya sebesar $56,5 \%$ dipengaruhi oleh variabel lain yang tidak termasuk dalam penelitian ini.

\section{c. Pengujian Hipotesis (Uji t)}

Uji t digunakan untuk mengetahui pengaruh variabel independen yaitu Non Performing Loan (NPL), Capital Adequacy Ratio (CAR), Return On Asset (ROA) dan BI Rate secara parsial terhadap variabel dependen yaitu penyaluran kredit. Hasil uji $t$ dalam penelitian ini dapat dilihat pada tabel 7 berikut ini: 
Tabel 7

Uji t

Coefficients $^{\mathrm{a}}$

\begin{tabular}{|ll|r|r|r|r|r|}
\hline \multirow{2}{*}{ Model } & \multicolumn{2}{|c|}{$\begin{array}{c}\text { Unstandardized } \\
\text { Coefficients }\end{array}$} & $\begin{array}{c}\text { Standardized } \\
\text { Coefficients }\end{array}$ & \multirow{2}{*}{$\mathrm{t}$} & \multirow{2}{*}{ Sig. } \\
\cline { 2 - 5 } & \multicolumn{1}{|c|}{$\mathrm{B}$} & \multicolumn{1}{c|}{ Std. Error } & \multicolumn{1}{c|}{ Beta } & & \\
\hline 1 & (Constant) & 208631.431 & 280151.300 & .165 & .745 & .459 \\
& $\mathrm{X}_{1}$ & 25063.181 & 14948.906 & -.169 & 1.677 & .098 \\
& $\mathrm{X}_{2}$ & -8421.370 & 5134.383 & .732 & -1.640 & .105 \\
& $\mathrm{X}_{3}$ & 117426.234 & 16258.111 & -.097 & 7.223 & .000 \\
& $\mathrm{X}_{4}$ & -29735.733 & 30655.261 & & -9.70 & .335 \\
\hline
\end{tabular}

Berdasarkan table diatas didapatkan hasil bahwa:

\section{H1 NPL berpengaruh negatif terhadap penyaluran kredit}

Berdasarkan hasil uji t pada tabel diatas, uji variabel independen NPL memiliki thitung lebih kecil dari tabel yaitu sebesar 1,677 < 1,994 dan nilai signifikasi 0,98 lebih besar dari 0,05. Berdasarkan hal tersebut maka $\mathrm{Ha}=$ ditolak, $\mathrm{Ho}=$ diterima. Jadi hipotesis pertama yang menyatakan NPL berpengaruh negatif dansignifikan terhadap penyaluran kredit ditolak.

\section{$\mathrm{H}_{2}$ CAR berpengaruh positif terhadap penyaluran kredit}

Berdasarkan hasil uji t pada tabel diatas, uji variabel independen CAR memiliki $t_{\text {hitung }}$ lebih kecil dari $t_{\text {tabel }}$ yaitu sebesar $-1,640<1,994$ dan nilai signifikasi 0,105 lebih besar dari 0,05. Berdasarkan hal tersebut maka $\mathrm{Ha}=$ ditolak, $\mathrm{Ho}=$ diterima. Jadi hipotesis kedua yang menyatakan CAR berpengaruh positif dan signifikan terhadap penyaluran kredit ditolak.

\section{H3 ROA berpengaruh positif terhadap penyaluran kredit}

Berdasarkan hasil uji t pada tabel diatas, uji variabel independen ROA memiliki $t_{\text {hitung }}$ lebih besar dari $t_{\text {tabel }}$ yaitu sebesar $7.223>1,994$ dan nilai signifikasi 0,000 lebih kecil dari 0,05. Berdasarkan hal tersebut maka $\mathrm{Ha}=$ diterima, $\mathrm{Ho}=$ ditolak. Jadi hipotesis ketiga yang menyatakan ROA berpengaruh positif dan signifikan terhadap penyaluran kredit diterima.

\section{$\mathrm{H}_{4}$ BI Rate berpengaruh positif terhadap} penyaluran kredit

Berdasarkan hasil uji t pada tabel diatas, uji variabel independen BI Rate memiliki thitung lebih besar dari tabelyaitu sebesar $-0,970<1,994$ dan nilai signifikasi 0,335 lebih besar dari 0,05. Berdasarkan hal tersebut maka $\mathrm{Ha}=$ ditolak, Ho = diterima. Jadi hipotesis ketiga yang menyatakan BI Rate berpengaruh positif dan signifikan terhadap penyaluran kredit diterima.

\section{PEMBAHASAN}

\section{Pengaruh NPL terhadap penyaluran} kredit

Hasil penelitian menunjukan variabel Non Performing Loan (NPL) berpengaruh positif dan tidak signifikan terhadap penyaluran kredit. Hal ini ditunjukan dari hasil pengujian hipotesisnya yang menunjukan $t_{\text {hitung }}$ lebih kecil dari tabel yaitu sebesar 1,677 $<$ 1,994 dan nilai signifikasi 0,98 lebih besar dari 0,05. Sehingga hipotesis yang berbunyi NPL berpengaruh negatif signifikan terhadap penyaluran 
kredit ditolak. Dimana hasil ini tidak sesuai dengan teori bahwa semakin tinggi tingkat NPL maka penyaluran kredit akan semakin rendah.

Hal ini berarti meskipun tingkat NPL naik maka tingkat penyaluran kredit juga akan meningkat, itu dikarenakan NPL yang terjadi pada bank yang terdaftar di Bursa Efek Indonesia masih belum melewati batas maksimum yang ditentukan oleh Bank Indonesia yaitu sebesar 5\%. Sehingga walaupun NPL yang terjadi pada tahun 2014-2016 mengalami peningkatan tetapi masih berada dibawah batas ketentuan maka penyaluran kredit pada bank juga akan tetap meningkat.

Hasil penelitian ini memperkuat hasil penelitian sebelumnya yang dilakukan oleh Oktaviani (2012) yang mengemukakan bahwa NPL berpengaruh positif tidak signifikan terhadap jumlah penyaluran kredit. Hal ini disebabkan Kemungkinan NPL berpengaruh positif dikarenakan NPL yang digunakan dalam penelitian adalah NPL selama tiga tahun, dimana bank dalam melakukan kebijakan penyaluran kredit merujuk pada NPL tahun lalu. Faktor kredit macet tentunya tidak akan lepas dari aktivitas utama bank berupa penyaluran kredit. Namun apabila terjadi kenaikan nilai NPL atau kredit yang bermasalah masih dalam batas wajar menurut pihak bank dan masih mampu dikendalikan oleh bank, maka bank tetap akan meningkatkan penyaluran kreditnya. Sebaliknya, nilai NPL kecil atau menurun bank tidak akan memaksimalkan penyaluran kredit, karena pihak bank tetap akan memperhatikan faktor-faktor lain seperti ketersediaan dana dan permodalan.

Pengaruh yang tidak signifikan pada NPL memiliki kecenderungan bahwa meningkatnya kredit yang diberikan memiliki kemungkinan terjadi NPL yang besar namun hal ini termasuk wajar terjadi karena peningkatan NPL akibat adanya peningkatan kredit. Namun jika terjadi nilai NPL yang tinggi melampaui batas maksimum ketentuan BI tentu saja akan membatasi bahkan menurunkan penyaluran kredit perbankan. NPL juga berpengaruh tidak signifikan terhadap penyaluran kredit, artinya jika jumlah dana yang disalurkan meningkat setiap periode dan NPLnya menunjukkan arah yang positif dikarenakan jumlah NPL pada perbankan masih pada batas terkendali dan bisa ditoleransi oleh Bank Indonesia (BI) yaitu maksimum 5\%, maka penyaluran kredit tidak akan dikurangi melainkan jumlahnya akan tetap ditingkatkan.

\section{Pengaruh CAR terhadap penyaluran kredit}

Hasil penelitian menunjukan variabel Capital Eduquecy Ratio (CAR) berpengaruh negatif dan tidak signifikan terhadap penyaluran kredit. Hal ini ditunjukan dari hasil pengujian hipotesisnya yang menunjukan

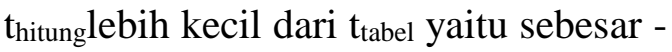
$1,640<1,994$ dan nilai signifikasi 
0,105 lebih besar dari 0,05 . Sehingga hipotesis yang berbunyi CAR berpengaruh positif signifikan terhadap penyaluran kredit ditolak.

Hasil penelitian ini memperkuat hasil penelitian sebelumnya yang dilakukan Darmawan,dkk (2017) yang menyatakan bahwa CAR berpengaruh negatif dan tidak signifikan terhadap penyaluran kredit perbankan. Kemungkinan CAR berpengaruh negatif dikarenakan suatu bank banyak memberikan pinjaman atau ekspansi kredit kepada masyarakat. Perlu untuk diingat bahwa kredit memiliki risiko yaitu risiko tidak tertagih. Semakin besar kredit yang diberikan, maka risiko kredit yang dihadapi bank akan semakin besar yang dapat membuat nilai ATMR akan mengalami kenaikan. Ketika nilai ATMR tinggi, nilai pembagi dalam rasio CAR akan semakin tinggi sehingga nilai CAR bank dapat menurun (kecil). Sebaliknya, jika CAR tinggi dapat menunjukkan bahwa ATMR rendah atau risiko kredit yang rendah. Jadi, dalam posisi ATMR yang rendah mengindikasikan bank sedang tidak banyak memberikan kredit kepada masyarakat sehingga kredit rendah.

\section{Pengaruh ROA terhadap} penyaluran kredit

Hasil penelitian menunjukan variabel Return On Assets (ROA) berpengaruh positif dan signifikan terhadap penyaluran kredit. Hal ini ditunjukan dari hasil pengujian hipotesisnya yang menunjukan thitung lebih besar dari tabel yaitu sebesar 7.223 $>1,994$ dan nilai signifikasi 0,000 lebih kecil dari 0,05. Sehingga hipotesis yang berbunyi ROA berpengaruh positif signifikan terhadap penyaluran kredit diterima.

Hasil penelitian ini sejalan dengan penelitian yang dilakukan oleh Putri dan Akmalia (2016) dan Saryadi (2013) yang menunjukan ROA memiliki pengaruh positif dan signifikan terhadap penyaluran kredit. Hasil serupa juga dikemukakan oleh Abundanti (2016) ROA berpengaruh positif terhadap penyaluran kredit pada bank umum.

Adanya perbedaan hasil antara penelitian ini dengan penelitian sebelumnya dimungkinkan terjadi karena perbedaan penggunaan tahun amatan dalam variabel ROA ini. ROA yang digunakan dalam penelitian ini adalah ROA tahun lalu. Dan hasilnya adalah variabel ROA berpengaruh signifikan terhadap penyaluran kredit oleh bank. Artinya, bank saat akan menawarkan kredit modal kerjanya berkaca pada ROA atau tingkat laba tahun lalu. Jika ROA tahun lalu sudah tinggi, maka bank dianggap sudah efektif dalam menggunakan asset yang dimiliki untuk menghasilkan laba.Bahkan jika laba yang diperoleh tinggi maka terdapat kemungkinan bagi bank untuk menyimpan laba dalam bentuk laba ditahan sehingga memungkinkan bank untuk dapat lebih banyak menyalurkan kredit. 


\section{Pengaruh BI Rate terhadap penyaluran kredit}

Hasil penelitian menunjukan variabel BI Rate berpengaruh negatif dan tidak signifikan terhadap penyaluran kredit. Hal ini ditunjukan dari hasil pengujian hipotesisnya yang menunjukan $t_{\text {hitung }}$ lebih besar dari $t_{\text {tabel }}$ yaitu sebesar $-0,970<1,994$ dan nilai signifikasi 0,335 lebih besar dari 0,05. Sehingga hipotesis yang berbunyi BI Rate berpengaruh positif signifikan terhadap penyaluran kredit ditolak.

Hasil penelitian ini memperkuat hasil penelitian sebelumnya yang dilakukan Putra dan Rustariyuni (2015) yang menyatakan bahwa BI Rate berpengaruh negatif dan tidak signifikan terhadap penyaluran kredit perbankan.

$\mathrm{BI}$ rate merupakan bunga kebijakan yang mencerminkan sikap atau stance kebijakan moneter yang ditetapkan oleh bank Indonesia dan diumumkan kepada publik. Pergerakan BI rate diharapkan akan diikuti oleh perkembangan di suku bunga deposito, dan pada gilirannya suku bunga kredit perbankan. Idealnya ketika terjadi kenaikan BI rate akan diikuti juga oleh kenaikan suku bunga deposito dan suku bunga kredit perbankan begitupun sebaliknya. Pergerakan suku bunga bank umum dipengaruhi juga oleh faktor- faktor internal bank umum itu sendiri misalnya, net interest margin, Biaya Operasional Pendapatan Operasional (BOPO), Non Performing Loans (NPL), komposisi kredit bank umum itu sendiri. Hubungan yang negative antara BI rate dengan penyaluran kredit bank umum di Indonesia mengartikan bahwa bank umum di Indonesia sepenuhnya beracuhan pada $\mathrm{BI}$ rate dalam menentukan kebijakan suku bunga kreditnya.

Nilai koefisien yang negatif dan tidak signifikan menunjukkan bahwa apabila tingkat bunga $\mathrm{BI}$ rate tinggi hal ini langsung mempengaruhi jumlah permintaan kredit pada bank umum. Hal tersebut dikarenakan ketika suku bunga $\mathrm{BI}$ rate dinaikkan oleh Bank Indonesia (BI), pihak bank umum langsung merespon kebijakan tersebut guna menurunkan tertekannya margin bank itu sendiri. Ketika suku bunga acuan dinaikkan, bank umum langsung menggunakan bunga bank yang terbaru sebagai acuan bunga pinjaman maupun simpanan mereka. Jadi dapat disimpulkan ketika BI rate dinaikkan hal tersebut langsung merespon suku bunga pada bank umum.

\section{Pengaruh NPL, CAR, ROA dan BI} Rate terhadap penyaluran kredit

Uji simultan bertujuan untuk mengetahui pengaruh seluruh variabel independen secara bersama-sama terhadap variabel dependen. Uji simultan dilakukan dengan menggunakan uji $\mathrm{F}$ dengan taraf signifikansi 5\%. Apabila probabilitas $F$ statistic $<0,05$ maka dapat disimpulkan bahwa secara bersama- sama seluruh variabel independen 
memiliki pengaruh signifikan terhadap variabel dependen.

Hasil penelitian menunjukan Non Performing Loan (NPL), Capital Adequacy Ratio (CAR), Return On Asset (ROA) dan BI Rate secara bersama-sama mempengaruhi penyaluran kredit secara signifikan. Hal ini ditunjukan dari hasil uji $\mathrm{F}$ yang menunjukan nilai $f$ hitung sebesar $13.459>\mathrm{f}$ table 2,50 dan signifikan hitung $0,000<0,050$. Ini menunjukkan bahwa variabel independen yang antara lain Non Performing Loan (NPL), Capital Adequacy Ratio (CAR), Return On Asset (ROA) dan BI Rate secara bersama-sama mempengaruhi penyaluran kredit secara signifikan.

Hasil penelitian ini memperkuat hasil penelitian sebelumnya yang dilakukan Serli (2016) dan Darmawan (2017) yang menyatakan bahwa NPL, CAR, ROA, dan BI Rate berpengaruh terhadap penyaluran kredit.

\section{KESIMPULAN DAN SARAN Kesimpulan}

Berdasarkan hasil penelitian diatas, maka dapat diambil kesimpulan sebagai berikut:

1. Non Performing Loan (NPL) berpengaruh positif dan tidak signifikan terhadap penyaluran kredit. Hal ini ditunjukan dari hasil pengujian hipotesisnya yang menunjukan $t_{\text {hitung }}$ lebih kecil dari tabelyaitu sebesar 1,677 < 1,994 dan nilai signifikasi 0,98 lebih besar dari 0,05 .

Vol. 11, No. 1, Juli 2020, Halaman 71-84
2 Capital Eduquecy Ratio (CAR) berpengaruh negatif dan tidak signifikan terhadap penyaluran kredit. Hal ini ditunjukan dari hasil pengujian hipotesisnya yang menunjukan $t_{\text {hitung }}$ lebih kecil dari tabel yaitu sebesar -1,640 $<1,994$ dan nilai signifikasi 0,105 lebih besar dari 0,05 .

3. Return On Assets (ROA) berpengaruh positif dan signifikan terhadap penyaluran kredit. Hal ini ditunjukan dari hasil pengujian hipotesisnya yang

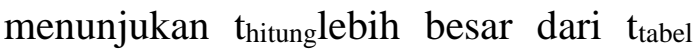
yaitu sebesar $7.223>1,994$ dan nilai signifikasi 0,000 lebih kecil dari 0,05.

4. BI Rate berpengaruh negatif dan tidak signifikan terhadap penyaluran kredit. Hal ini ditunjukan dari hasil pengujian hipotesisnya yang menunjukan thitung lebih besar dari tabel yaitu sebesar $-0,970$ $<1,994$ dan nilai signifikasi 0,335 lebih besar dari 0,05 .

5. Non Performing Loan (NPL), Capital Adequacy Ratio (CAR), Return On Asset (ROA) dan BI Rate secara bersama- sama mempengaruhi penyaluran kredit secara signifikan. Hal ini ditunjukan dari hasil uji $\mathrm{F}$ yang menghasilkan nilai $\mathrm{f}$ hitung sebesar $13.459>\mathrm{f}$ table 2,50 dan signifikan hitung $0,000<0,050$.

\section{Saran}

1. Bagi peneliti selanjutnya untuk memasukan faktor internal dan eksternal selain yang digunakan dalam penelitian ini guna meneliti bagaimana pengaruhnya terhadap jumlah penyaluran kredit 
2. Perlu menggunakan periode pengamatan yang lebih lama sehingga nantinya akan memberikan hasil yang lebih akurat tentang penyaluran kredit perbankan.

\section{DAFTAR PUSTAKA}

Boediono. 2014. Seri Sinopsis Pengantar Ilmu - No. 5 Ekonomi Makro; BPFE, Yogyakarta.

Dendawijaya, Lukman. 2008. Manajemen Perbankan; Ghalia Indonesia, Bogor.

Febrianto, Dwi Fajar. 2013. Analisis Pengaruh Dana Pihak Ketiga, LDR, $M P L, C A R, R O A$, dan BOPO

Terhadap Jumlah Penyaluran Kredit (Studi pada Bank Umum yang Terdaftar di BEI Periode Tahun 2009-2012); Skripsi. Universitas Diponegoro.

Firdaus, Rachmat dan Maya, Ariyanti. 2009. Manajemen Perkreditan Bank Umum: Teori, Masalah, Kebijakan dan Aplikasi Lengkap dengan Analisis Kredit; Alfabeta, Bandung.

Ismail. 2010. Manajemen Perbankan: dari Teori Menuju Aplikasi; Kencana, Jakarta.

2010. Majanemen Perbankan; Kencana Prenada Media Group, Jakarta.

Jensen \& Meckling. 1976. The Theory of The Firm : Manajerial Behaviour, Agency Cost, and Ownership

Vol. 11, No. 1, Juli 2020, Halaman 71-84
Structure; Journal of Financial and Economic, 3:305-360

Kasmir. 2008. Bank dan Lembaga Keuangan Lainnya; Edisi Revisi 2008, PT. RAJAGRAFINDO PERSADA, Jakarta. . 2010. Manajemen Perbankan; Edisi Revisi 2008, Raja Grafindo Persada, Jakarta.

. 2013. Bank dan Lembaga Keuangan Lainnya; Rajawali Pers, Jakarta.

Kuncoro, M. \& Suhardjono. 2011. Manajemen Perbankan Teori dan Aplikasi. BPFE, Yogyakarta.

Novianto, Aditya. 2011. Analisis Pengaruh Nilai Tukar (Kurs) Dolar Amerika/Rupiah (US\$/Rp), Tingkat Suku Bunga SBI, Inflasi dan Jumlah Uang Beredar (M2) Terhadap Indeks Harga Saham Gabungan (IHSG) Di Bursa Efek Indonesia (BEI) Periode 1999.1 - 2010.6;

Skripsi. Universitas Diponegoro Semarang.

Nugraheni, Putri Pratista dan Wahyu Meiranto. 2013. Pengaruh Faktor Internal Bank dan Sertifikat Bank Indonesia Terhadap Penyaluran Kredit Perbankan di Indonesia; Diponegoro Journal of Accounting. Vol. 2, No. 4, Hal. 1-11. Universitas Diponegoro.

Oktaviani, Irene Rini Demi Pangestuti. 2012. Pengaruh DPK, ROA, CAR, NPL dan Jumlah SBI Terhadap Penyaluran Kredit Perbankan Periode 2008-2011; Jurnal. Fakultas Ekonomika dan Bisnis Universitas Diponegoro. Semarang. 
PBI No. 17/11/PBI/2015 tanggal 25 Juni 2015 tentang Perubahan Atas Peraturan Bank Indonesia Nomor 15/15/PBI/2013 tentang Giro Wajib Minimum Bank Umum Dalam Rupiah Dan valuta Asing Bagi Bank Umum Konvensional

Peraturan Bank Indonesia Nomor 14/18 / PBI/2012 tanggal 28 November 2012 tentang Kewajiban Penyediaan Modal Minimum Bank Umum

Rosmilia, R. 2009. Pelaksanaan Penyelesaian Kredit Bermasalah; Tesis Magister, tidak diterbitkan, Universitas Diponegoro, Semarang.

Satrio, B. Haryanto dan Endang, T. Widyarti. 2017. Analisis Pengaruh NIM, NPL, BOPO, BI Rate dan $C A R$ terhadap penyaluran kredit bank umum Go Public Periode 20122016; Diponegoro Journal of Management. Vol:56 No.4 tahun 2017

Sugiyono.2012. Metode Penelitian Pendidikan Pendekatan

Kuantitatif, Kualitatif, dan $R \& D$;

Alfabeta, Bandung. .2014. Metode Penelitian Pendidikan Pendekatan Kuantitatif, Kualitatif, dan $R \& D$; Alfabeta, Bandung.

Surat Edaran Bank Indonesia No.6/23/DPNP Sistem Penilaian Tingkat Kesehatan Bank Umum dan lampiran tanggal 31-05-2004

Syofian, Siregar.2014. Metode Penelitian Kuantitatif; Kencana, Jakarta.
Taswan. 2010. Manajemen Perbankan Konsep, Teknik, dan Aplikasi; Edisi kedua, Yogyakarta.

Tenrilau. 2012. Analisis Pengaruh Dana Pihak Ketiga (DPK), Capital Adequacy Ratio (CAR), dan Non Performing Loan (NPL) Terhadap Penyaluran Kredit Perbankan (Studi pada Bank Persero di Indonesia Periode 2005-2010);

Undang -Undang Republik Indonesia Nomor 10 Tahun 1998 Tentang Perubahan Atas Undang -Undang Nomor 7 Tahun 1992 Tentang Perbankan.

Undang-Undang Republik Indonesia No 10, Tahun 1998, tentang Perbankan

www.idx.co.id 